\title{
The Impact of Foreign Direct Investment by Economic Activity on Gross Domestic Product Growth in Kosovo
}

\author{
Prof. Ass. Dr. Florije Govori \\ Faculty of Economics, \\ University of Prizren, Kosovo \\ MSc. Amant Fejzullahu \\ Project Manager, \\ Prosperify GmbH, Switzerland
}

DOI: https://doi.org/10.36941/ajis-2020-0113

\begin{abstract}
The effects of the foreign direct investment (FDI) on economic growth, both in developed and non-developed countries, have been investigated for decades. In Kosovo's new economy, the FDI's presence is essential for economic and social development. This study aims to examine the impact of FDI by economic activities, known as "high-level aggregation," on the gross domestic product (GDP) growth for the period 2010-2019. The multiple regression is used to analyze the strength and direction of the FDI's impact on the GDP. The results show that FDI in the activities belonging to the primary sector has negatively impacted the GDP. In contrast, the FDI in activities of the secondary sector indicates a positive impact. Concerning the tertiary sector, the result differs among the types of activities. The FDI in real estate, renting, and business activities have a positive impact on GDP. Also, the FDI in public administration, education, human health, and social work activities has a substantial impact on GDP growth. The other FDIs belonging to the tertiary sector showed adverse impacts. So, the findings suggest that in a new economy, the FDI in activities that are more apt to induce positive externalities has more potential to increase the GDP in the long run. Otherwise, the impact may be low or adverse.
\end{abstract}

Keywords: foreign direct investment, gross domestic product, economic activity, Kosovo

\section{Introduction}

For decades, the effects of foreign direct investment (FDI) in the host countries have gained attention among many researchers. Regardless of the economic development level, through attractive, wellstructured national investment strategies, countries worldwide compete for FDI. Strategies must comply with conditions that ensure sustainable development, including macroeconomic stability, political predictability, social coherence, and the rule of law. In this way, the policies should be consistent with acceptable global practices such as investment policy, promotion, and facilitation of investment, competition and tax policy, public and corporate governance, human resources development, rural development, innovation, the green growth investment policy, and other related policies (OECD, 2015).

The role of FDI arises by their impact on economic welfare. Developed countries compete in attracting FDI to keep economic growth or to induce growth in times of stagnation. While developing countries attempt to attract FDI to reduce dependency on the primary sector by industrializing the economy. Developing countries may be capable of benefiting more from FDI after reaching a certain level of development in education and health, infrastructure, technology, and financial markets (OECD, 2002). 
Thus, the appropriate infrastructure, the level of educational and labour skills, and the improvement of the business climate are essential in attracting FDI, from which also the local investors can benefit. A sound model of such attractive incentives thought to be Ireland and Sweden (Blomstrom \& Kokko, 2003).

The World Investment Report (UNCTAD, 2018) points out that the primary sources of external finance in developing economies are FDI with $39 \%$ and remittances with $24 \%$. As specified in this document, the FDI represents a relevant source of funds that can generate productive capacity in developing countries. However, both with portfolio equity are shown the most expensive type of external finance due to a higher required rate of return.

As for the divestment, the factors that drive foreign divestment decisions are the increase of unit labour costs, average tariff rate, trade openness, exchange rate volatility. Also, the level of corruption control, the labour market's inefficiency, and environmental policy stringency are considered the driver of foreign divestment decisions. Another essential factor may be regional trade agreements (Borga, Flores, \& Sztajerowska, 2019). The Global Divestment Study Report (2019) notes that companies' divestment decisions mainly relate to the sector convergence, the new technology investments, and the macroeconomic and geopolitical triggers.

Concerning efforts to attract FDI, Kosovo has made gradual progress, particularly in recent years in regulatory reforms, to make more comfortable doing business and was ranked 57th among 190 countries (World Bank, 2019). However, widespread informality and corruption, inefficient judiciary, and the weak rule of law and institutions remain the critical obstacles (EBRD, 2020).

For the observed ten-year period, the FDI in Kosovo, in general, show a downward trend. The decrease in FDI occurred due to the high repatriation of foreign firms' profits for repayments of debt, which reduced the scope for reinvestment of earnings, estimates the European Commission (2019). Seen by the section, the FDI in Real estate, renting, and business activities show a high growth trend. A steady upward trend of the investments in Other services is apparent. At the same time, Electricity, gas, and water supply, and Hotels and restaurants show a weak upward trend (Figure 1).

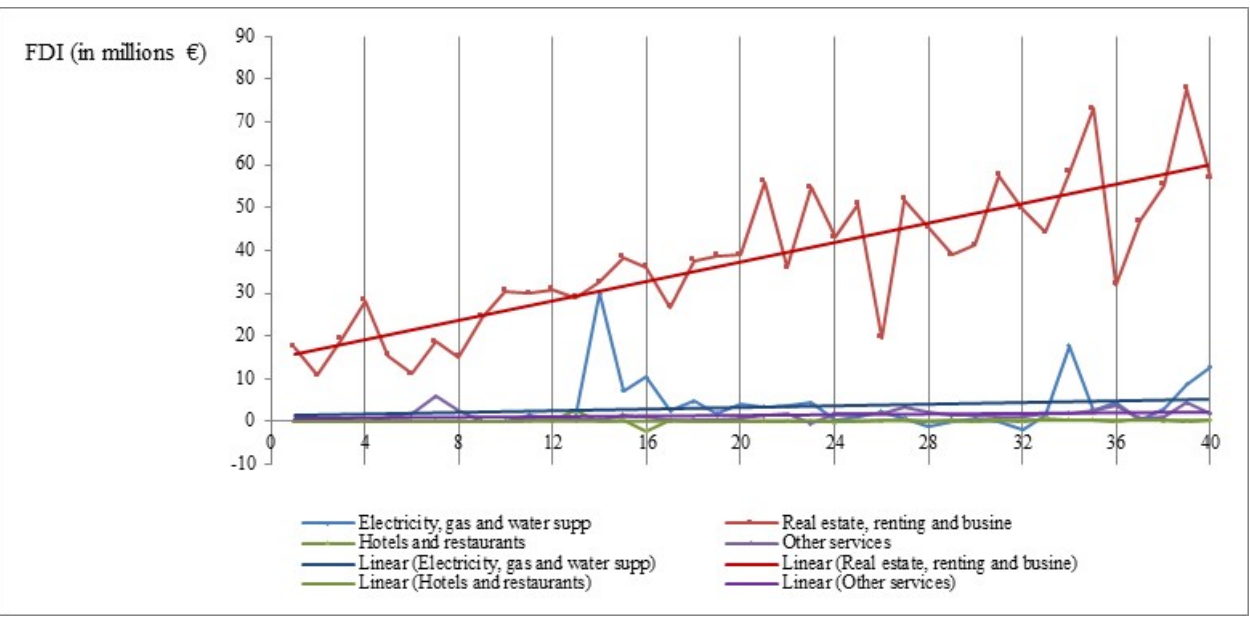

Figure 1: Trend Analysis for DE, I, L, and OPQ

Source: Authors estimates based on data from the Kosovo Agency of Statistics (2020) and Central Bank of the Republic of Kosovo (2020).

On the contrary, activities such as Construction, Manufacturing, Other not elsewhere classified, and Transport, storage, and communication show a downward trend (Figure 2). Financial intermediation, Wholesale, retail trade, repair of motor vehicles, Mining and quarrying, and Agriculture, hunting, forestry, and fishing, also show a downward trend (Figure 3). Considering the above, the study aims to examine the direction and magnitude of the FDIs' impact on GDP growth. 


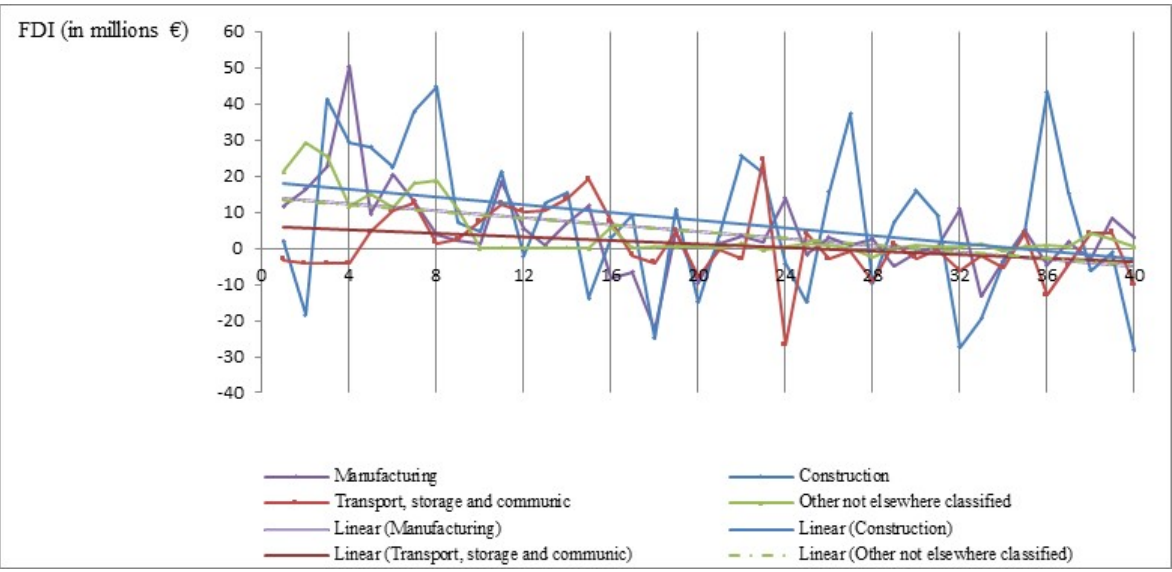

Figure 2: Trend Analysis for C, F, HJ, and RSTU

Source: Authors estimates based on data from the Kosovo Agency of Statistics (2020) and Central Bank of the Republic of Kosovo (2020).

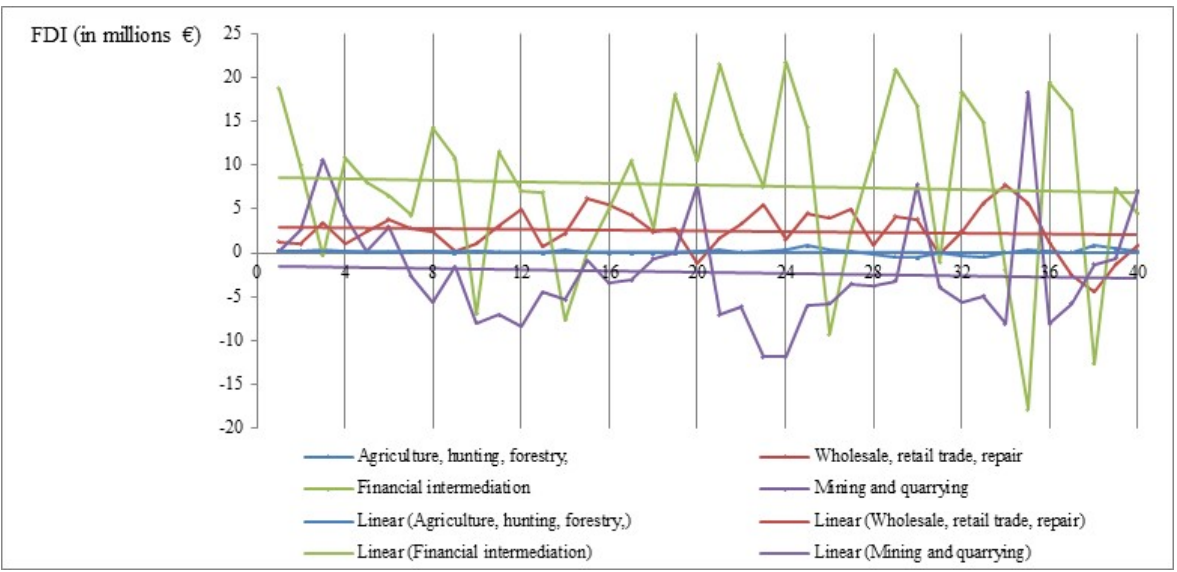

Figure 3: Trend Analysis for A, B, G, and K

Source: Authors estimates based on data from the Kosovo Agency of Statistics (2020) and Central Bank of the Republic of Kosovo (2020).

\section{Literature Review}

Various research studies have examined FDI and its effects on economies of the host countries concerning the benefits and externalities they generate. These researches examine the effects of FDI from various perspectives. Theoretical and empirical data on the effects of FDI on GDP provide distinct findings and suggestions. These dissimilarities closely relate to the economic and socio-political characteristics of the host countries. The findings can also be influenced by the duration of the period observed. FDI's aggregation form is another component that affects results.

Alfaro (2003) analyzed the effect of FDI on economic growth through flows into the different sectors of the economy. The author found that FDI inflows into the primary sector negatively affected growth. In contrast, FDI inflows in the manufacturing sector have a positive effect on growth. The evidence about FDI inflows into the service sector was ambiguous. Moudatsou (2003) examined the effects of FDI on the 
growth of EU economies. The evidence shows that in separately examined each country, current FDI inflows do not affect current growth while the past level of FDI does. The results also, directly and indirectly, indicate the positive effect of FDI on the growth of EU economies, with the data pooled.

The positive impact of FDI on economic growth in developing countries theoretically and empirically was challenged by Herzer (2010). After examining the nature of the growth effect of FDI, the author found that the effect of FDI on growth in developing countries is negative on average. Relating to country-specific factors that explain the differences in the growth effects of FDI, the growth effects depended positively on the level of freedom from government intervention and business regulation, and negatively on the FDI volatility and the natural resource dependence. The factors that played an indirect role in the FDI effects on growth were found to be the level of per capita income, property rights, and the freedom from corruption. Curwin \& Mahutga (2014) studied the FDI effects on economic growth from post-socialist transition countries. The findings suggest that FDI penetration has a negative association with economic growth in the short and long term and may lead to an economic contraction, in case it increases too quickly. On the contrary, domestic investment has a positive association and continually led to expansion.

Aitken \& Harrison (1999) found a positive relationship between foreign equity participation and plant productivity in small enterprises and the adverse effects of foreign investment on the productivity of domestically owned plants in Venezuela. Concerning the externalities of FDI in host countries, the evidence suggests that foreign firms' presence raises the average wage level and improves overall productivity (Lipsey, 2004). In attempting to link the gap between the theoretical and empirical literature on the effects of FDI on growth, Alfaro et al. (2006) found that FDI led to higher growth rates in financially developed countries than financially poorly developed countries. Among the findings was the critical role of human capital in allowing growth benefits from FDI to materialize. Regarding the impact of MNEs on wages and working conditions, the evidence shows that effects vary in complicated ways across different types of investments, workforce groups, and economic environments (OECD-ILO, 2008).

That the FDI's effect on economic growth depends on the level of human capital available in the host economy has been proved by Borensztein et al. (1995). The positive relationship between FDI at the aggregate level, and real income per capita, was found by Khawar (2005). Roy \& Berg (2006) revealed that even an industrially advanced country benefits from FDI, and the gains from FDI are significant in the long run. Behname's (2012) study shows that FDI has a positive effect on Southern Asia's economic growth and that human capital, trade, economic infrastructure, and capital had a positive effect on attracting FDI. Dinh et al. (2019) proved that FDI capital inflow in emerging and developing economies hinder economic growth in the short run. In the long run, the positive effect depends on the type, sector, scope, duration, and other characteristics of these investments. A positive relationship between the FDI and information and communication technology and the economic growth in the Asia-Pacific developing countries was found by Sinha \& Sengupta (2019).

The study by Ferrer \& Zermeno (2015) about the causal relation between FDI and GDP shows no such causality in Brazil, South Korea, Peru, and Mexico. In the case of China, the relationship was found to be contrary to the predicted direction. That is, GDP growth caused an increase in FDI. Agrawal (2015) found that FDI and economic growth at the group level are long-run integrated, and the Granger causality test confirms the presence of bidirectional causality between economic growth and FDI. Zghidi et al. (2016) found a strong positive relationship between FDI and economic growth in four North African countries. Dkhili \& Dhiab (2018), too, found a positive relationship between economic freedom with economic growth and with FDI, in the case of Gulf Cooperation Council countries.

Blomstrom \& Kokko (2003) suggested that focusing the investment incentives mainly in foreign firms proves to be an inefficient mechanism to raise national welfare. The potential spillover benefits of FDI actualized if local firms had the ability and motivation to invest in absorbing foreign technologies and skills. So, the investment incentives policies should be available on fair terms to foreign as well as local investors. Onyeiwu \& Shrestha (2004) found that significant factors for FDI flow to Africa were the economic growth, inflation, the openness of the economy, international reserves, and natural resource availability. 
The study by Prasad et al. (2007) shows that nonindustrial countries that relied on foreign capital had not grown faster than those not relying on foreign capital. However, the reliance of these countries on domestic rather than foreign saving to finance investment resulted consequently in less investment and consumption than they would be if they could draw in foreign capital as industrial countries. Harding \& Javorcik (2011) suggest that investment promotion can be an effective instrument to attract FDI in developing countries, but not in industrialized economies. Blonigen \& Jeremy (2011) examine the relationship between government policies and encourage of the FDI. They pointed out that policies that negotiate bilateral agreements in mergers and acquisitions affected FDI inflow.

\section{Methodology}

To measure the correlation between variables and the extent to which they move together is used the Pearson correlation test. We examined the effect of FDI on GDP growth using the multiple regression analysis. The sample consists of quarterly data for the period from 2010-2019. The group of activities (CBK, 2020) is based on the Statistical classification of economic activities in the European Community, NACE Rev.2, known as "high-level aggregation" (Eurostat, 2008). The regression function is as follows:

$\mathrm{GDP}=$

$\beta_{0}+\beta_{1} A+\beta_{2} B+\beta_{3} C+\beta_{4} D E+\beta_{5} F+\beta_{6} G+\beta_{7} I+\beta_{8} H J+\beta_{9} \mathrm{~K}+\beta_{10} L+\beta_{11} \mathrm{OPQ}+\beta_{12} R S T U+\varepsilon$

where:

Unknown coefficients:

$\beta$ o - intercept,

$\beta_{1}, \beta_{2}, \beta_{3} \ldots \beta_{12}-$ unknown regression coefficients,

$\varepsilon$ - the margin of error within the regression model.

Dependent variable:

GDP - gross domestic product.

Independent variables that represent the FDI by activity:

A - Agriculture, hunting, forestry, and fishing;

$\mathrm{B}$ - Mining and quarrying;

C - Manufacturing;

DE - Electricity, gas, and water supply;

F - Construction;

$\mathrm{G}$ - Wholesale, retail, trade, and repairs of motor vehicles;

I - Hotels and restaurants;

HJ - Transport, storage, and communication;

$\mathrm{K}$ - Financial intermediation;

$\mathrm{L}$ - Real estate, renting, and business activities;

OPQ - Other services;

RSTU - Other activities not elsewhere listed.

\section{Results and Discussion}

The descriptive statistics for the observed period show that the FDIs were focused mainly on Real estate, renting, and business activities, followed by Financial intermediation, Construction, Other activities not elsewhere listed, and Manufacturing. Next come the Electricity, gas, and water supply, Wholesale, retail, trade, and repairs of motor vehicles, and Other services. With the least average are Transport, storage, and communication, Hotels and restaurants, Agriculture, hunting, forestry, and fishing. During this period, Mining and quarrying had a negative average (Table 1). 
Table 1: Descriptive Statistics

\begin{tabular}{|c|c|c|c|c|c|c|c|}
\hline Variable & Total Count & Mean & SE Mean & St Dev & Sum of Squares & Minimum & Maximum \\
\hline A & 40 & 0,1216 & 0,0425 & 0,2687 & 3,4065 & $-0,5009$ & 0,8222 \\
\hline B & 40 & $-2,17$ & 0,971 & 6,141 & 1659,156 & $-11,892$ & 18,305 \\
\hline C & 40 & 4,46 & 1,85 & 11,73 & 6160,4 & $-22,34$ & 50,48 \\
\hline $\mathrm{DE}$ & 40 & 3,243 & 0,926 & 5,857 & 1758,738 & $-1,753$ & 29,954 \\
\hline $\mathrm{F}$ & 40 & 7,5 & 3,11 & 19,68 & 17358,18 & $-28,18$ & 44,75 \\
\hline G & 40 & 2,505 & 0,393 & 2,488 & 492,335 & $-4,426$ & 7,791 \\
\hline I & 40 & 0,167 & 0,0882 & 0,5581 & 13,2628 & $-2,1159$ & 2,4485 \\
\hline $\mathrm{HJ}$ & 40 & 1,03 & 1,46 & 9,23 & 3368,68 & $-26,86$ & 24,41 \\
\hline $\mathrm{K}$ & 40 & 7,74 & 1,52 & 9,64 & 6023,81 & $-17,84$ & 21,79 \\
\hline $\mathrm{L}$ & 40 & 37,97 & 2,57 & 16,24 & 67948,17 & 10,77 & 77,81 \\
\hline OPQ & 40 & 1,425 & 0,202 & 1,276 & 144,747 & $-0,49$ & 5,907 \\
\hline RSTU & 40 & 4,54 & 1,26 & 7,99 & 3315,47 & $-2,43$ & 29,19 \\
\hline GDP & 40 & 1428,2 & 42,2 & 266,6 & 84364810,5 & 901,6 & 1967,4 \\
\hline
\end{tabular}

Source: Authors estimates based on data from the Kosovo Agency of Statistics (2020) and Central Bank of the Republic of Kosovo (2020).

Pearson test shows a high positive correlation of the GDP with the Real estate, renting, and business activities, and a moderate positive correlation with Other services. A moderate positive correlation also shows up in the Other activities not elsewhere classified, with the Mining and quarrying, Manufacturing, and Construction. An inverse correlation appeared in the Financial intermediation with the GDP, Agriculture, hunting, forestry and fishing, Mining and quarrying, Electricity, gas, and water supply, and Transport, storage, and communication. Same, the Real estate, renting, and business activities move in the reverse direction with the Manufacturing, Construction, and Other activities not elsewhere classified (Table 2).

Table 2: Pearson Correlation

\begin{tabular}{|c|c|c|c|c|c|c|c|c|c|c|c|c|}
\hline & A & B & C & DE & $\mathrm{F}$ & G & I & $\mathrm{HJ}$ & $\mathrm{K}$ & $\mathrm{L}$ & OPQ & RSTU \\
\hline $\bar{B}$ & $\begin{array}{c}-0,035 \\
0,83\end{array}$ & & & & & & & & & & & \\
\hline \multirow[t]{2}{*}{ C } & 0,208 & 0,204 & & & & & & & & & & \\
\hline & 0,197 & 0,207 & & & & & & & & & & \\
\hline \multirow[t]{2}{*}{$\mathrm{DE}$} & 0,154 & $-0,061$ & $-0,167$ & & & & & & & & & \\
\hline & 0,343 & 0,707 & 0,302 & & & & & & & & & \\
\hline \multirow[t]{2}{*}{$\mathrm{F}$} & 0,076 & $-0,052$ & 0,341 & $-0,137$ & & & & & & & & \\
\hline & 0,641 & 0,751 & 0,032 & 0,399 & & & & & & & & \\
\hline \multirow[t]{2}{*}{ G } & $-0,306$ & $-0,062$ & $-0,071$ & 0,151 & 0,073 & & & & & & & \\
\hline & 0,055 & 0,706 & 0,661 & 0,353 & 0,654 & & & & & & & \\
\hline \multirow[t]{2}{*}{ I } & $-0,1$ & $-0,012$ & $-0,022$ & $-0,119$ & $-0,039$ & $-0,093$ & & & & & & \\
\hline & 0,541 & 0,943 & 0,891 & 0,466 & 0,812 & 0,567 & & & & & & \\
\hline \multirow[t]{2}{*}{$\mathrm{HJ}$} & 0,011 & -0,077 & 0,064 & 0,165 & 0,189 & 0,27 & 0,053 & & & & & \\
\hline & 0,944 & 0,635 & 0,697 & 0,309 & 0,243 & 0,092 & 0,744 & & & & & \\
\hline \multirow[t]{2}{*}{ K } & $-0,32$ & $-0,295$ & 0,027 & $-0,354$ & 0,004 & $-0,07$ & $-0,057$ & $-0,351$ & & & & \\
\hline & 0,044 & 0,064 & 0,871 & 0,025 & 0,981 & 0,667 & 0,725 & 0,026 & & & & \\
\hline \multirow[t]{2}{*}{$\mathrm{L}$} & 0,129 & 0,024 & $-0,303$ & 0,251 & $-0,384$ & $-0,044$ & 0,1 & $-0,076$ & $-0,153$ & & & \\
\hline & 0,426 & 0,885 & 0,057 & 0,119 & 0,014 & 0,788 & 0,54 & 0,641 & 0,345 & & & \\
\hline \multirow[t]{2}{*}{ OPQ } & 0,162 & 0,011 & $-0,045$ & 0,011 & 0,228 & 0,099 & 0,011 & $-0,12$ & $-0,028$ & 0,213 & & \\
\hline & 0,317 & 0,948 & 0,784 & 0,946 & 0,157 & 0,542 & 0,947 & 0,461 & 0,863 & 0,187 & & \\
\hline \multirow[t]{2}{*}{ RSTU } & 0,161 & 0,328 & 0,474 & $-0,258$ & 0,303 & $-0,111$ & $-0,201$ & $-0,004$ & 0,045 & $-0,634$ & 0,002 & \\
\hline & 0,32 & 0,039 & 0,002 & 0,108 & 0,057 & 0,496 & 0,214 & 0,979 & 0,783 & o & 0,99 & \\
\hline \multirow[t]{2}{*}{ GDP } & 0,105 & 0,04 & $-0,22$ & 0,281 & $-0,172$ & $-0,051$ & $-0,013$ & $-0,149$ & $-0,314$ & 0,743 & 0,42 & $-0,535$ \\
\hline & 0,518 & 0,805 & 0,173 & 0,079 & 0,29 & 0,756 & 0,935 & $0,35^{8}$ & 0,048 & $\begin{array}{c}1 / 43 \\
0\end{array}$ & 0,007 & o \\
\hline
\end{tabular}

Cell Contents

Pearson correlation

P-Value

Source: Authors estimates based on data from the Kosovo Agency of Statistics (2020) and Central Bank of the Republic of Kosovo (2020). 
The coefficient of multiple determination shows that the model explains $76 \%$ of GDP variation (Table 3). The normal distribution of variables was checked by the Shapiro Wilk test, Anderson Darling test, and D'Agostino tests (Table 4). Given that the study focuses on the independent variables' weight on GDP growth, multicollinearity is also tested. The analysis shows that the variance inflation factors are below 3, which are at an acceptable level (Table 5).

Table 3: Analysis of Variance

\begin{tabular}{|c|c|c|c|c|c|c|c|}
\hline Source & DF & Seq SS & Contribution & Adj SS & Adj MS & F-Value & P-Value \\
\hline Regression & 12 & 2107738 & $76,02 \%$ & 2107738 & 175645 & 7,13 & o \\
\hline A & 1 & 30779 & $1,11 \%$ & 51075 & 51075 & 2,07 & 0,161 \\
\hline B & 1 & 5359 & $0,19 \%$ & 3898 & 3898 & 0,16 & 0,694 \\
\hline $\mathrm{C}$ & 1 & 191480 & $6,91 \%$ & 24266 & 24266 & 0,99 & 0,33 \\
\hline DE & 1 & 138467 & $4,99 \%$ & 3060 & 3060 & 0,12 & 0,727 \\
\hline F & 1 & 14070 & $0,51 \%$ & 4807 & 4807 & 0,2 & 0,662 \\
\hline G & 1 & 8247 & $0,30 \%$ & 37657 & 37657 & 1,53 & 0,227 \\
\hline I & 1 & 500 & $0,02 \%$ & $5575^{\circ}$ & $5575^{\circ}$ & 2,26 & 0,144 \\
\hline $\mathrm{HJ}$ & 1 & 65276 & $2,35 \%$ & 61359 & 61359 & 2,49 & 0,126 \\
\hline $\mathrm{K}$ & 1 & 223599 & $8,06 \%$ & 189995 & 189995 & 7,72 & 0,01 \\
\hline $\mathrm{L}$ & 1 & 1205575 & $43,48 \%$ & 306827 & 306827 & 12,46 & 0,002 \\
\hline OPQ & 1 & 167822 & $6,05 \%$ & 199865 & 199865 & 8,12 & 0,008 \\
\hline RSTU & 1 & 56565 & $2,04 \%$ & 56565 & 56565 & 2,3 & 0,141 \\
\hline Error & 27 & 664774 & $23,98 \%$ & 664774 & 24621 & & \\
\hline Total & 39 & 2772513 & $100,00 \%$ & & & & \\
\hline \multicolumn{8}{|c|}{ Model Summary } \\
\hline $\mathrm{S}$ & R-sq & R-sq(adj) & PRESS & R-sq(pred) & & & \\
\hline 156,912 & $76,02 \%$ & $65,37 \%$ & 1664745 & $39,96 \%$ & & & \\
\hline
\end{tabular}

Source: Authors estimates based on data from the Kosovo Agency of Statistics (2020) and Central Bank of the Republic of Kosovo (2020).

Table 4: Normality Test

\begin{tabular}{lcc} 
Test & Test Ho: Normal & P-Value \\
\hline Shapiro Wilk & 0,980 & 0,6964 \\
Anderson Darling & 0,292 & 0,6052 \\
D'Agostino Skewness & 0,453 & 0,6502 \\
D'Agostino Kurtosis & $-0,186$ & 0,8524 \\
D'Agostino Omnibus & 0,240 & 0,8868 \\
Durbin-Watson $=\mathbf{2 , 2 9 2 9 2}$ & & \\
\hline
\end{tabular}

Source: Authors estimates based on data from the Kosovo Agency of Statistics (2020) and Central Bank of the Republic of Kosovo (2020).

The FDI in economic activities belonging in the primary sector, such as Agriculture, hunting, forestry, and fishing, had a negative effect on GDP. Agriculture, hunting, forestry, and fishing distinguish with high exposure to the risk of fluctuations in the price of products in regional and global markets. The low returns and the low average wages of workers are also characteristic of these economic activities. Furthermore, weather conditions such as floods, hail, winds, and droughts play a vital role in the variety, quality, and volume of the output. Therefore, governments pay funds in the form of subsidies to support farmers. Another factor that may influence this negative impact is the $27 \%$ drop in funds invested in the past ten years.

FDI in Mining and quarrying have also negatively affected GDP growth. Apart from the high 
exposure to the risk of price fluctuations, the negative effect of these activities on GDP for ten years observed occurred due to an excessive drop in the amount of FDI in Mining and quarrying, which surpassed the investing amount near 2.4 times more (Figure 4 ). Thus, considering the above, the effects of these activities on GDP have been adverse. The negative impact of the primary sector FDIs on growth was also found by Alfaro (2003), Aykut \& Sayek (2005), and Hanafy (2015).

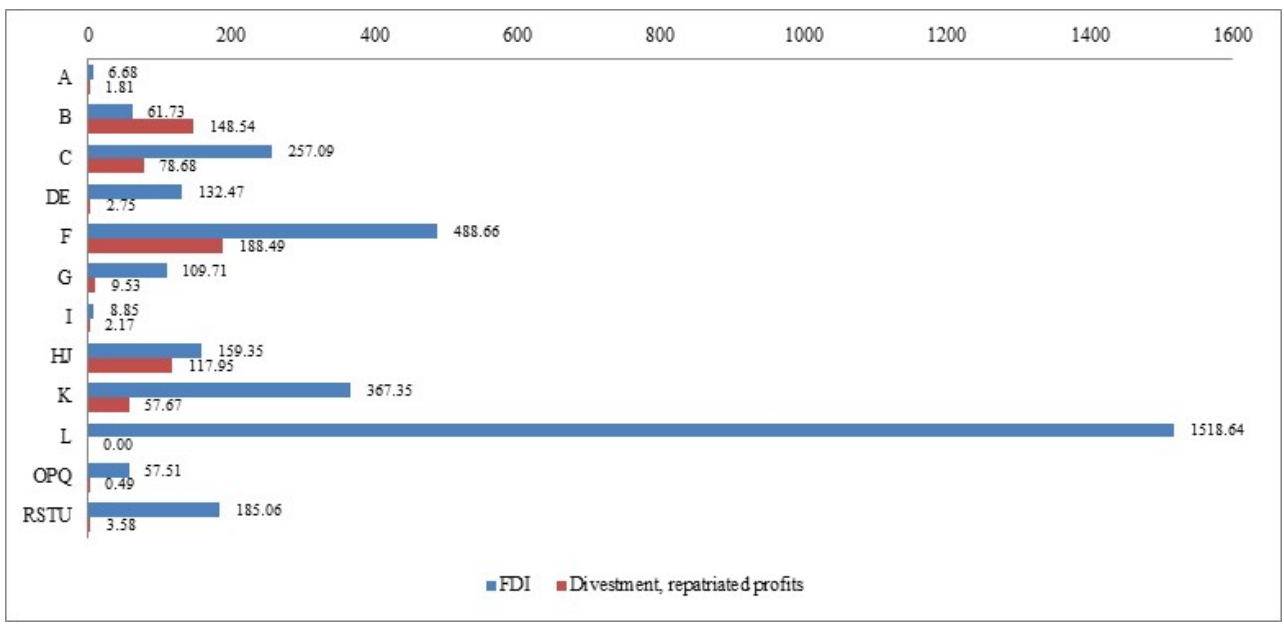

Figure 4: FDI by section for the period 2010-2019 (in millions $€$ )

Source: Authors estimates based on data from the Kosovo Agency of Statistics (2020) and Central Bank of the Republic of Kosovo (2020).

Manufacturing is thought to be an engine for a country's economic and social development, which boosts efficiency, generates new jobs, and improves the living standard. While from 2014 till 2019, Agriculture, hunting, forestry, and fishing percentage in GDP declined from $11 \%$ to $7 \%$, and Mining and quarrying remained at an unvaried percentage of almost 2, the Manufacturing share in GDP grew by an average of $0.25 \%$ per year (Kosovo Agency of Statistics, 2019). As such, the manufacturing sector counts for $11.51 \%$ of GDP, with $2.5 \%$ that constitute the FDI. Although with a low share in GDP, the regression coefficient shows a positive effect of these FDI on GDP growth.

By the FDI in Electricity, gas, and water supply activities, which improved infrastructure in related fields, benefited all economic activities. These investments also lead to induce GDP growth. A weak positive effect on GDP growth had the FDI in Construction. Concerning the decline in FDI, construction ranked third (with nearly $39 \%$ of the total amount invested in this activity through the observed period). As this industry employs a large number of workers, this decline has, to some extent, weakened the positive effect on GDP.

On the contrary, the FDI in Wholesale, retail, trade, and motor vehicle repairs negatively impacted GDP growth. This impact mainly ensued by the import of goods, which has a twofold effect on GDP. On the one hand, imports directly worsen the trade balance. On the other hand, imported goods by competing to domestically produced goods have hindered domestic production's potential positive effects on GDP growth.

Similarly, FDI in Transport, storage and communication, and Hotels and restaurants, negatively influenced the GDP. As for FDI in Other activities not elsewhere listed, including arts, entertainment, recreation, and other service activities, there is evidence indicating a high negative impact on GDP growth. Some of the adverse effects noted above may have the same causal factors, which stem from the high funding costs and low productivity. These adverse effects may also have been influenced by the informality that dominates these economic activities (Cojocaru, 2017). The adverse effects of the 
Financial intermediation FDIs on the GDP may be related to the high fees and commissions, costly lending to borrowers, and profits repatriation.

A strong effect on the GDP growth proved to have the FDI in Real estate, renting, and business activities. Nearly eight times more potent on GDP growth than the latter turns out to be the FDI in Other services such as public administration, education, human health, and social work activities. So, the main contributors to GDP growth seem to be the FDI in activities that typically generate positive externalities, which arise in the long run.

Table 5: Regression Coefficients

\begin{tabular}{lcccccc} 
Term & Coef & SE Coef & $95 \%$ CI & T-Value & P-Value & VIF \\
\hline Constant & 1164 & 121 & $(916 ; 1412)$ & 9,63 & 0 & \\
A & -177 & 123 & $(-429 ; 75)$ & $-1,44$ & 0,161 & 1,72 \\
B & $-2,11$ & 5,31 & $(-13,00 ; 8,77)$ & $-0,4$ & 0,694 & 1,68 \\
C & 2,61 & 2,63 & $(-2,78 ; 7,99)$ & 0,99 & 0,33 & 1,5 \\
DE & 1,75 & 4,97 & $(-8,44 ; 11,94)$ & 0,35 & 0,727 & 1,34 \\
F & 0,7 & 1,58 & $(-2,54 ; 3,94)$ & 0,44 & 0,662 & 1,53 \\
G & $-14,5$ & 11,7 & $(-38,6 ; 9,6)$ & $-1,24$ & 0,227 & 1,35 \\
I & $-72,5$ & 48,2 & $(-171,3 ; 26,3)$ & $-1,5$ & 0,144 & 1,14 \\
HJ & $-5,1$ & 3,23 & $(-11,73 ; 1,53)$ & $-1,58$ & 0,126 & 1,41 \\
K & $-9,78$ & 3,52 & $(-17,01 ;-2,56)$ & $-2,78$ & 0,01 & 1,83 \\
L & 8,75 & 2,48 & $(3,66 ; 13,83)$ & 3,53 & 0,002 & 2,57 \\
OPQ & 65,5 & 23 & $(18,3 ; 112,6)$ & 2,85 & 0,008 & 1,36 \\
RSTU & $-8,12$ & 5,36 & $(-19,12 ; 2,87)$ & $-1,52$ & 0,141 & 2,91 \\
\hline
\end{tabular}

Source: Authors estimates based on data from the Kosovo Agency of Statistics (2020) and Central Bank of the Republic of Kosovo (2020).

\section{Conclusions}

In this article, we analyzed the impact of FDI by activities on the GDP growth for ten years. After examining the data, the results show that five out of the twelve industries have positively affected growth, while others had adverse effects. Concerning FDI in the primary sector, the coefficients indicated adverse effects by different magnitude on GDP. In this regard, the effects have been influenced by product characteristics and by divestment/repatriation of the firm's profits. Also, the negative downward trend function in Mining and quarrying influenced the inverse relation of FDI in these activities with GDP.

Economic activities belonging in the secondary sector are positively related to GDP growth. Even with a downward trend that in the last three years falls in the negative region of the respective functions, the FDIs in Manufacturing and Construction positively affect on GDP growth. Electricity, gas, and water supply also positively impacted GDP. Unlike the last two, these FDI has a moderate upward trend and a decline of only 2 percent.

Concerning the impact of the FDI in services on the GDP growth, results vary amongst activities. The FDI in Real estate, rental, and business activities, distinguished with a high growth trend function, had a strong positive relationship with GDP. The FDI in Public administration, education, human health, and social work activities also show a robust positive relationship with GDP, albeit with a weak upward trend function. The other FDI in the services led to decreases in GDP.

\section{References}

Agrawal, G. (2015). Foreign Direct Investment and Economic Growth in BRICS Economies: A panel Data Analysis. Journal of Economics, Business and Management, Vol. 3 (4). 421-424. 
Aitken, B. J., \& Harrison, A. E. (1999). Do Domestic Firms Benefit From Direct Foreign Investment? Evidence From Venezuela. American Economic Review, 89(3) , 605-618 http://dx.doi.org/10.1257/aer.89.3.605.

Alfaro, L. (2003). Foreign Direct Investment and Growth: Does the Sector Matter? Harvard Business School , 1-32.

Alfaro, L., Chanda, A., Kalemli-Ozcan, S., \& Sayec, S. (2006). How does Foreign Direct Investment Promote Economic Growth? Exploring the Effects of Financial Markets on Linkages. NBER Working Paper No.12522, https://www.nber.org/papers/w12522.

Aykut, D., \& Sayek, S. (2005). The Role of the Sectoral Composition of Foreign Direct. https://ecomod.net/sites/default/files/document-conference/ecomod2005/1124.pdf.

Behname, M. (2012). Foreign Direct Investment and Economic Growth: Evidence from Southern Asia. Economic Analysis Working Papers (2002-2010). Atlantic Review of Economics (2011-2016), 2, issue , number 02. , 1-14 http://www.unagaliciamoderna.com/eawp/coldata/upload/14_Foreign_Direct_Investment.pdf.

Blomstrom, M., \& Kokko, A. (2003). The Economics of Foreign Direct Investment Incentives. National Bureau of Economic Research. Cambridge, Working Paper 9489. 1-26.

Blonigen, B. A., \& Jeremy, P. (2011). Determinants of Foreign Direct Investment. NBER Working Paper 16704, 1-49 http://www.nber.org/papers/w16704.

Borensztein, E., Gregorio, J., \& Lee, J.-W. (1995). How does foreign direct investment affect economic growth? NBER Working Paper No. 5057 , 1-29 National Bureau of Economic Researche, Cambridge.

Borga, M., Flores, P. I., \& Sztajerowska, M. (2019). Drivers of divestment decisions of multinational enterprises - A cross-country firm-level perspective. Paris, France https://dx.doi.org/10.1787/5a376df4-en: OECD Working Papers .

CBK. (2020, April 24). https://bqk-kos.org/?id=55. Retrieved from https://www.bqk-kos.org/: https://bqkkos.org/repository/docs/time_series/33\%2oForeign\%2odirect\%2oinvestments\%20-\%2oby\%2osector.xls

Cojocaru, A. (2017). Kosovo Jobs Diagnostic. Jobs Diagnostic Kosovo . World Bank, Washington, DC. License: Creative Commons Attribution CC BY 3.o IGO.

Curwin, K. D., \& Mahutga, M. C. (2014). Foreign Direct Investment and Economic Growth: New Evidence from PostSocialist Transition Countries. Social Forces, Volume 92, Issue 3, 1159-1187.

Dinh, T. T.-H., Vo, D. H., Vo, A.-T., \& Nguyen, T. C. (2019). Foreign Direct Investment and Economic Growth in Short Run and Long Run: Empirical Evidence from Developind Countries. Journal of Risk and Financial Management, 12 (4): 176. https://doi.org/10.339o/jrfm12040176.

Dkhili, H., \& Dhiab, L. B. (2018). The relationship between Economic Freedom and FDI versus Economic Growth: Evidence from the GCC Countries. Journal of Risk and Financial Management, $11(4), 81$. https://www.mdpi.com/1911-8074/11/4/81\#.

EBRD. (2020). Transition Report 2019-20. London. http://www.ebrd.com/documents/oce/transition-report-201819kosovo.pdf: European Bank for Reconstruction and Development.

European Commission. (2019). Commission Staff Working Document - Kosovo 2019 Report. Brussels: European Commission.

Eurostat. (2008). NACE Rev. 2 Statistical classification of economic activities in the European Community. Chapter 5, pp 47. Luxembourg: Office for Official Publications of the European Communities. https://ec.europa.eu/eurostat/documents/3859598/5902521/KS-RA-07-015-EN.PDF. Luxembourg Office for Official Publications of the European Communities: Office for Official Publications of the European Communities.

Ferrer, C. E., \& Zermeno, E. V. (2015). Foreigh direct investment and gross domestic product growth. International Conference on Applied Economics, ICOAE 2015 (pp. 198-207). Kazan, Russia: Procedia Economics and Finance.

(2019). Global Divestment Study Report. https://assets.ey.com/content/dam/ey-sites/eycom/en_gl/topics/divestment/2019/global_divestment_study_report.pdf: Global Corporate Divestment Study.

Hanafy, S. (2015). Sectoral FDI and economic growth: Evidence from Egyptian governorates. MAGKS Joint Discussion Paper Series in Economics, No.37-2015, Philipps-University Marburg, School of Business and Economics, Marburg, 1-35. http://hdl.handle.net/10419/129286.

Harding, T., \& Javorcik, B. S. (2011). Roll out the Red Carpet and They Will Come: Investment Promotion and FDI Inflows. The Economic Journal. Volume 121 (557) , 1445-1476.

Herzer, D. (2010). How does foreign direct investment really affect developing countries' growth? IAI Discussion Papers, No. 207, Georg-August-Universitat Gottingen, Ibero-America Institute for Economic Research (IAI), Gottingen, 1-31.

Khawar, M. (2005). Foreign Direct Investment and Economic Growth: A Cross-Country Analysis. Global Economy Journal , 5(1), 1-11.

Kosovo Agency of Statistics. (2019). Gross Domestic Product Q4 2018. Prishtina: Kosovo Agency of Statistics. 
Kosovo Agency of Statistics. (2020). Gross Domestic Product $Q_{4}$ 2019. Prishtina. https://ask.rksgov.net/media/5372/gross-domestic-product-gdp-of-the-expenditure-and-production-q4V-2020.pdf: Kosovo Agency of statistics.

Lipsey, R. E. (2004). Home- and Host-Country Effects of Foreign Direct Investment. In Challenges to Globalization: Analyzing the Economics (pp. 333-382). University of Chicago Press URL: http://www.nber.org/chapters/c9543.

Moudatsou, A. (2003). Foreign Direct Investment and Economic Growth in the European Union. Journal of Economic Integration, 18(4), 689-707.

OECD. (2002). Foreign Direct Investment for Development - Maximising Benefits, Minimising Costs. Paris, France. https://www.oecd.org/investment/investmentfordevelopment/1959815.pdf: Organisation for Economic Cooperation and Development.

OECD. (2015). Policy Framework for Investment 2015 Edition. Paris. http://dx.doi.org/10.1787/9789264208667-en : OECD Publishing.

OECD-ILO, C. o. (2008, June 23-24). The Impact of Foreign Direct Investment on Wages and Working Conditions. Paris, France: OECD.

Onyeiwu, S., \& Shrestha, H. (2004). Determinants of Foreign Direct Investment in Africa. Journal of Developing Societies, 20(1-2):89-106. doi:10.1177/0169796X04048305.

Prasad, E. S., Rajan, R. G., \& Subramanian, A. (2007). Foreign Capital and Economic Growth. NBER Working Paper Series , 1-64 National Bureau of Economic Research, Cambidge.

Roy, A. G., \& Berg, H. F. (2006). Foreign Direct Investment and Economic Growth: A Time-Series Approach. Global Economy Journal, 6(1), Retrieved 26 Feb. 2020, from doi:10.2202/1524-5861.1130.

Sinha, M., \& Sengupta, P. P. (2019). FDI inflow, ICT Expansion and Economic Growth: An Empirical Study on AsiaPacific Developing Countries. Global Business Review, https://doi.org/10.1177\%2Fo972150919873839.

UNCTAD. (2018). World Investment Report. Geneva: United Nations.

World Bank. (2019). Doing Business 2020 : Comparing Business Regulation in 190 Economies - Economy Profile of Kosovo (English). Washington DC. http://documents.worldbank.org/curated/en/573681575004008429/pdf/DoingBusiness-2020-Comparing-Business-Regulation-in-19o-Economies-Economy-Profile-of-Kosovo.pdf: Doing Business 2020. Washington, D.C. : World Bank Group.

World Bank. (2019). Enterprise Surveys www.enterprisesurveys.org The World Bank Group. Washington DC. https://www.enterprisesurveys.org/content/dam/enterprisesurveys/documents/country/Kosovo-2019.pdf: The World Bank.

Zghidi, N., Sghaier, I. M., \& Abida, Z. (2016). Does Economic Freedom Enhance the Impact of Foreigh Direct Investment on Economic Growth in North African Countries: A Panel Data Analysis. African Development Review, 28(1), 64-74. https://doi.org/10.1111/1467-8268.12167. 